\title{
Metástasis cutánea como primera manifestación de progresión en el carcinoma vesical urotelial
}

\author{
Donate Moreno MJ, Pastor Navarro H, Carrión López P, Salinas Sánchez AS, \\ Lorenzo Romero JG, Ruiz Mondéjar R, Virseda Rodríguez JA.
}

Servicio de Urología. Complejo Hospitalario Universitario de Albacete.

Actas Urol Esp. 2007;31(7):802

Las metástasis en piel por un carcinoma vesical urotelial es una manifestación poco común y se asocia con un mal pronóstico. Presentamos un caso en el que la metástasis cutánea fue la primera manifestación metástasica, hecho infrecuente puesto que suelen presentarse habitualmente en fases avanzadas de la enfermedad.

Se trata de un varón de 79 años, diagnosticado en Septiembre de 2004 de carcinoma urotelial vesical infiltrante. Se realizó cistoprostatectomía radical y derivación urinaria tipo Bricker. Estadío postoperatorio pT3BNxMx, borde quirúrgico libre aunque emboliza vasos linfáticos. A los 13 meses de la intervención presenta unas lesiones eritematosas, nodulares e induradas confluyentes a nivel de hemiabdomen inferior hasta raíz de miembros inferiores. La biopsia cutánea es compatible con metástasis de carcinoma. Se inicia tratamiento quimioterápico según esquema Carboplatino AVC-Gemcitabina. Las lesiones cutáneas progresaron apareciendo sobreinfección por anaerobios y maceración a nivel del estoma que impedía el manejo por el paciente por lo que se hizo necesario la colocación de nefrostomía percutánea bilateral.

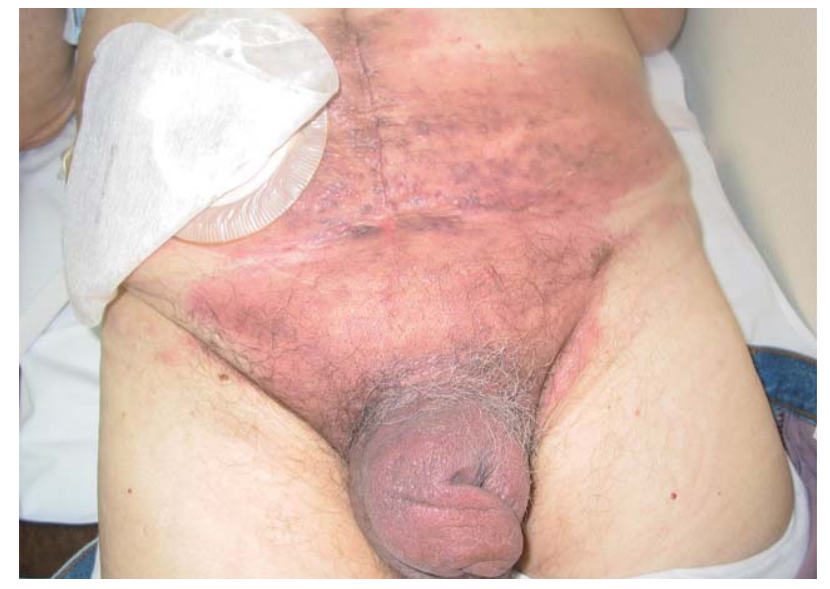

FIGURA 1

Estudios de imagen posteriores objetivaron progresión metastásica ósea y pulmonar. El paciente falleció a los 21 meses de la cirugía por proceso séptico de origen urinario.

Correspondencia autor: Dra. $\mathrm{M}^{\mathrm{a}} \mathrm{J}$. Donate Moreno

Servicio de Urología. Complejo Hospitalario Universitario de Albacete. Hermanos Falcó, s/n - 02006 Albacete

Tef.: 967597100

E-mail autor: donajiu@ono.com

Información artículo: Imágenes en Urología

Trabajo recibido: mayo 2006

Trabajo aceptado: junio 2006 